are necessary for the cuisine of the sick-room and nursery', $I$ ' think I could do so very briefly. In addition to the resources of the domestic kitchen and larder, the sick-room kitchen should contain'a suipply of the following flours : oat, maize, malt, and lentil flours in a finely pulverised condition, and freed from bran. It should be provided with a solution of soda-bicarbonate of known strength. 'This' would be of use to add to milk when necessary, and to assist in the preparation of peptonised articles of food. Next to these would come a reliable pancreatic extract, and a preparation of pepsin or rennet for the production of whey. The associated apparatus should include a thermometer, wherewith the nurse could, when desirable, heat up cold-made meat-infusions to a proper temperature, and regulate the warmth required in the predigestion of food. A double-cased saucepan would form an indispensable item; this makes an admirable hot-water bath for the preparation of beef-tea and fortified gruels. A pair of acales, glass-measures, and a mincing-machine would complete the list. Finally, there should be, for the service of the nurse, a card or sheet containing plain directions for the preparation of the various kinds of liquid food. ${ }^{4}$

Given these simple appliances, I see no difficulty, in these days of skilled nursing, in the medical attendant being able to prescribe almost any kind of liquid food for his patients in any combination, and having it served up for the invalid in the most suitable possiblemanner. I have ascertained that there is no difficulty on the part of the miller in producing meals from malt, oats, or lentils, freed from bran and coarser particles, and in nearly as fine a state of preparation as wheaten flour. In this state, these meals are susceptihle of much more rapid and perfect cooking than when roughly ground. I have little sympathy with much that has been said of the advantages of whole meal and decorticated flour. It has been alleged that the too complete separation of the outer parts of the grain deprives the flour of its mineral matter. If we lived on bread alone, there would be some force in this objection; but as that is not so, and that we find in milk, meat, fish, eggs, soups, and fresh vegetables, a superabundant provision of mineral matter, and have, moreover, always at our elbows a supply of salt, there can never be any lack of salipe materials in our food. The branny matter of the flour is both indigestible and irritating to the primæ viæ; and although it may not injure, or may even be useful, to the strong and healthy, it is quite an unfit element in food designed for the weak and tender membranes of the invalid and infant.

Gentlemen, in bringing.my remarks to a close, I should like again to press for a more systematic and a more comprehensive study of dietetics. The effects of diet are profound and far-reaching, and exceedingly subtle. Some inkling of this is got from the history of gout. You all know how slowly and how insidiously the gouty diathesis is developed under the influence of diet, and how it may affect the descendants unto the third and fourth generations. The immediate effects of diet are often not the most important. Behind these are remote sequences of vital concern to the family and the nation. And it is not solely in regard to feeding the sick that a scientific knowledge of dietetics is useful. There are public questions of great moment, affecting the food-habits of the people, the consideration of which ought not to be dominated exclusively by popular opinion. In legislating on such questions, it is of the last importance to proceed on correct lines; for it is certain that any policy which ignores the instincts of mankind and the laws of nature is foredoomed to failure. I believe that a comprehensive study of these questions from the side of history, and of natural history, would throw unexpected light on the issues involved, and furnish data of great value for the guidance of the legislator and of the social reformer.

4 Messrs. Paine and Benger (Mottershead and Co., chemists, Manchester) have put together the ingredients and apparatus above enumerated in a portable box of which a sample was exhibited at the annual museum.

Massage of the Prostate for Retention.-A Dutch surgeor, Dr. Le Rütter, has found means to subject the prostate to a kind of massage, and in this way has completely cured two patients of the ages of "over 50 " and 70 respectively. The method employed is to pass the forefinger up the rectum, and then to move the prostate to the right, left, and in a vertical direction three times each way, rubbing it firmly afterwards. This proceeding is, as may be supposed, rather disagreeable to the patient (to say nothing of the operator's sensations), and it cannot be borne for long at a time. In one of the cases, 20 massages, and, in the other, 15 , were required to offect complete restoration of the power to pass urine freely. In both, a small amount of bleeding took place from the urethra, caused by the manipulation of the prostate, for which liquor ferri sesquichloridi was given, with a satisfactory result.

\section{ADDRESS IN PUBLIC MEDICINE.}

\author{
THOMAS JONES DYKE, F.R.C.S.,
} Medical Officer of Health for Merthyr-Tydnl.

THE SANITARY HISTORY OF MERTHYR-TYDFIL.

IN this address, I propose, very briefly, to state the more prominent facts in the health-history of Merthyr-Tydfil, believing, with Dr. Norman Chevers, that, to pourtray in truthful words the unfavourable influences which have been detrimental to the health of the people who have resided in this upland valley, and to relate the beneficial results which have followed upon the removal of those influences, by the introduction of means promotive of good health, will be of as much value as the charming story told by one of the most eminent of sanitarians, of an ideal city of health.

The parish of Merthyr-Tydfil is situated at the upper part of the valley of the Taff, near the confluence of the greater and lesser Taff rivers, at a distance of 17 to 26 miles north of Cardiff. The area of the parish is nearly 18,000 acres ; it is about nine miles in length, wedge-shaped, being four miles wide at the northern part, lessening to a point at its southern end. Along the whole length, the Taff River runs in a deep valley, the ridges of mountains on each side rising to heights from 1,000 to 1,600 feet above the sea. The two rivers have their sources near the 'summits of the Breconshire Beacons, nearly 3,000 feet above the sea. Necessarily, the climate is cold and wet, the rainfall averaging 57 inches annually.

The old town of Merthyr is placed in the centre of the valley at its widest part, 500 feet above the sea. Along the valley, and following the courses of the streams flowing into the Taff, many villages and towns-especially the town of Dowlais on the north-east, and the district of Cyfarthfa on the north-west-have from time to time been formed, as the works for the manufacture of iron and for the getting of coal have sprung up.

Sir Henry de la Beche says : "The rocks on which the town stands form that stratification of coal-beds, shales, and sandstones known as the coal-measures, with which, in this district and for a long line of country, are intermixed beds of clay ironstone." To these ironstones formerly, but now to the beds of steam-coal, and to the limestone quarried in immediate proximity on the north of the parish, MerthyrTydfil owes its importance, as one of the principal seats of the iron and steel manufacture, and of the districts whence annually are exported the far-famed smokeless steam-coal.

In his report to the General Board of Health in 1850, the Inspector, Mr. Rammell, says : "The rise of Merthyr-Tydfil as a seat of industry and wealth may be attributed to the period when the use of pit-coal, instead of charcoal, was found applicable to the working of iron. About 1748 , the Dowlais district was leased by an ancestor of the Lewises, of Llanishen, in conjunction with an ancestor of the Guests of Dowlais. In 1755, Mr. Bacon obtained a lease for 99 years of a mineral tract, full of coal and iron ore; the whole of the leasehold interest in this property passed, at the close of the last century, into the hands of the Crawshays, of Cyfarth'a. Other mineral districts, as Penydarran and Plymouth, were taken at almost nominal rents."

The population of Merthyr Parish, in 1801, was 7,705; in 1881, 41,857 ; and, in 1885 , it was estimated at 52,500 , occupying 10,438 houses. The houses of the working classes (that is, of 45,000 out of the 52,000 inhabitants) are three- or four-roomed cottages; two rooms on the ground-floor, and one or two on the first story. They are built of a sandstone which is frequently of a very porous nature, and the ground-floors are mostly paved with stone. Those houses which were first built, when the iron-works were being established (1750 to 1780) were chiefly built against a wall of earth, and hence these have always been damp and unventilated.

Sir Henry de la Beche, reporting in 1843-4, says : "There was no water-supply ; there were some privies at the fow decent houses, but none to cottages. Slops and refuse were thrown on to unmetalled and unchannelled highways and streets, and on mounds of coal-ashes at every turn. There was a great number of poor, as indicated by the fact that between 6,000 and 7,000 persons, out of a population of 37,000 (one out of six), were relieved from the poor-rates annually."

In 1849, Mr. Rammell states: "The town of Merthyr-Tydfil was entirely destitute of drainage; no provision was made for excrementremoval; there was an utter want of a proper provision for supplying 
the town with water; in the few wells which existed, the water was bad in quality, from natural hardness or from impurities which had permested through the soil into the wells. There were 21 burialgrounds in various parts of the town."

In 1852, Dr. William Kay was temporarily elected officer of health. Ho concluded his report thus : "Tho unhealthiness of Merthyr is attributable to local and self-created conditions, the vicious construction of houses, the inadequate supply of water, the absence of drainago, and the nocessary consequences-accumulation of filth, atmos. phoric impurity, and extensive and fatal prevalence of disease."

Mr. Simon, then medical officer to the Privy Council, in his ninth ennual report, writing of Merthyr, said : "In our statistics, it showed orery possible evidence of sanitary neglect; in fever, in diarrhœa, in cholera, in small-pox, in phthisis, and other lung-diseases, and in mortality of children, it always was conspicuously bad, and the watersupply was cruelly scant and disgustingly foul."

I cannot better sum up the description of an unhealthy town than by quoting the statistics collected by Dr. George Buchanan, and published in the above-cited report.

"During the period of 11 years, 1846-1855, before any sanitary works were in actual operation, except the removal of accumulated mounds of ashes, etc., the death-rate from all causes, at all ages, was 332 per 10,000 inhabitants; the death-rate of children under one year, from all causes, $80 t$; of persons of all ages from fever, excluding typhus, $21 \frac{1}{3}$; from diarrhuea, at all ages, $11 \frac{1}{4}$; from phthisis, between ages of 15 and $55,38 \frac{2}{8}$ per 10,000 of the population.

I will leave this disagreeable picture of the results of long-continued neglect, and turn to a brighter ono.

\section{Sayitary Works axd Statistical Results.}

The Board of Health was formed in 1850 ; an accomplished surveyor was appointed ; the inspection of streets, lanes, and houses was estab. lished; the daily removal of house-refuse was provided for ; paving, channelling, and, in a few instances, drainage-works wore carried out. An Act was obtained by a private company to supply the town with water; the powers granted to the company were transferred to the local board, who directed Mr. Hawksley to carry out his scheme, and, in 1860, a partial supply was afforded from standpipes, free to all who desired to fetch water therefrom; and, in 1862, nearly the whole of the houses in Merthyr and Dowlais received a constant supply of water, averaging threo degrees of hardness, free from any pollution. The length of mains and branch water-pipes laid was $68 \frac{1}{2}$ miles.

During the carlier years of the Board's labours, 1850 to 1855, the progress was very slow; but during the second period of ten years, 1856 to 1865 , the sanitary work accomplished bore abundant fruit, for the death-rate from all causes was reduced to 271 per 10,000 ; that of infants to 67 ; that from fever, at all ages, to $10 \frac{1}{2}$; from phthisis to $37 \frac{1}{2}$; and from diarrhoes to 9 per 10,000 .

The third period of ten years, from 1866 to 1875 , was profitably occupied in the construction of main and branch sewers, and of all the sanitary appliances attached thereto, while the Board were assiduous in requiring the attention of their officers to the diligent search for causes of disease, and the early removal of any discovered cause. The sewers were commenced in 1865 , and completed in 1868 ; 55 miles in length of main and lateral sewers were constructed. The sewage was conveyed in mains to a point three and a half miles from the centre of the town ; there a mixture of lime and alum was added to the stream, which then florred onward to the straining tanks. The dissolved sewage passed through the materials for straining, and was run into the River Taff, half a mile below the village of Troedyrhiw. A now colliery, that of Merthyr Vale, was at this time established on the east bank of the Taff, about a mile below the outlet of the sewage into the river; a nuisance was undoubtedly caused, an injunction was obtained, and the work of connecting residences with the main sewers was arrested until 1872. Happily for Merthyr, the publication of Dr. Bdward Frankland's report on the proper means to be used for the filtration of sewage, had attracted the attention of Mr. J. Bailey Denton, who, in a paper real at Maidstone on November 24th, 1870, explained his views as to the practical mode to be adopted to earry out the clarifying of sewage suggested by Dr. Frankland.

By the direction of the late Lord Justice James (a Merthyr man), Mr. Bailey Denton was directed to try practically the method suggested; the filtering areas were formed near the outlet of the sewers, the sewage was passed over the prepared land, and Dr. Frankland reported that, on June $10 \mathrm{th}, 1871$, when the sewage-stream of 800,000 gallons per day was being passed over 10 acres of prepared land, "the water entering the Taff from the Merthyr intermittent filters was considerably purer than the Thames water, which wo aro often compelled to drink in London." This work having been completed, the con- nection of closets with the drains was proceeded with, 80 that in 1875 nearly all the properties in Merthyr and Dowlais wero properly drained.

It is very satisfactory to be able to say that the offinent water from the filtration areas was in June, 1885, the same as it was stated to have been in June, 1871, "considerably purer than the Thames water supplied to London." This fact is made apparent by the following epitome of the analyses. The Thames water-supply contained 28 grains of solids per gallon; the effluent water $11 \frac{1}{8}$ grains; the organic carbon in the Thames water was one-fifth of a grain, in the effluent one-tenth of a grain; the total combined nitrogen in the Thames water onefourth of a grain, in the effluent one-sixth of a grain per gallon. The filtration areas were so skilfully designed, and so well formed, the surface of the soil has been 80 carefully cleansed, that no clogging of the subsoil has occurred. The permeation of the strained sewage through six feet ol earth has gone on continuously for fourteen years; and the oxidation of nitrogenous matter is as thoroughly effected now, as it was when Dr. Frankland reported on the system.

The results of the care exhibited, and of the supply of pure water, pure air, and increased cleanliness in and around dwellings, were the diminution of the death-rate at all ages from 332 to 256 per 10,000 , of deaths of infants under one year to 65, of deaths from fevers to 6, from phthisis to $21 \frac{1}{2}$, and from diarrhoea to 4 per 10,000 ; while the average age at death, stated by Dr. Kay to be $17 \frac{1}{2}$ years in 1851, was in. creased to 25 years.

During the fourth period of nine years, 1876 to 1884 , in addition to the various works I have indicated, the Board arranged for the purchase and laying out of nearly 400 acres of land on a plain about six miles from the site of the filtering areas. These lands were laid out by the Board's surveyor, Mr. Samuel Harpur, for the disposal of sewage by wide irrigation. It became also necessary to provide reservoir at a point further north, in the valley of the lesser Taff river, to supply water to the town of Dowlais (in lieu of the expensive pro. cess of pumping from the Merthyr supply-basins) and to the rising village of Treharris. The whole of the works of inspection, of careful cleansing of filtering basins, and of regular flushing of water-mains, were assiduously carried out.

The results were, that the death-rate at all ages fell to 232 per 10,000 , that of infants to 50 , that from fevers to 38 , that from phthisis to $18 \frac{1}{2}$, and that from diarrhœa to 3 per 10,000 .

I should tell you, also, that three outbreaks of cholers occurred in the parish; in 1849, when the death.rate per 10,000 people from this malady was 267 ; in 1854 , when the rate was 83 ; and in 1866 , when it fell to 20 per 10,000 . The proportion of deaths from choler to population in the year 1849 , before any sanitary works were begun, was one out of every 30 ; while the proportion in 1866, when cleansing refuse, channelling and metalling roadways, had been done, and an excellent water-supply had been afforded, the death-rate from cholera and choleraic diarrhoea was only one out of every 400 of the people.

The outcome of these figures is this. The death-rate from all canses has been lessened by 30 years of sanitary work from 332 to 232 per 10,000 ; the deaths of infants under one year from 80 to 50 per 10,000; that from fevers from 21 to $3 \frac{7}{8}$; that from phthisis from 38 to $18 \frac{1}{2}$; from diarrhoes from 11 to 3 per 10,000 ; while the arerage age at death has been increased from $17 \frac{1}{2}$ years to 27 years.

You will ask how it is that, while the death-rates from so many maladies have been so greatly lessened, the general death-rate still remains so high as 232 per 10,000 . The answer will be found in the following statement of the rates of mortality from acute lung-disesses, at all ages, during the periods of time I have cited. Thus, in the first period, 1845 to 1855 , the rate was 28 per 10,000 ; in 1856.65 , it increased to 35 ; in 1866.75 it was 43 ; and in 1876-84, it was raised to 47 per 10,000 .

Much of the proclivity to bronchial catarrh and its sequences must undoubtedly be ascribed to the locality in which our population resides, a parish situated high amongst the mountains, having a wet and cold climate, and a soil sparingly permeable to water; much, also, must be due to the characteristics of the labours of the working men. Some, engaged at the iron and steel works, are exposed to all weathers at all hours of the night as well as day; labouring either at the blazing furnace, the boiling steel, or the glowing rail ; others are occupied as colliers, toiling half a mile underground in a heatod atmosphere, impregnated with coal-gases and cosl-dust, and, when labour is done, raised to the earth's surface at the pit's mouth, on the bleak monntain-side, borne homewards in railway-carriages, or painfully trudging across lofty heaths to their cottage homes. The liability to chills, induced by such compulsory modes of life, must be apparent;
and this liability, together with the vicissitudes of climate, will account for the extreme prevalence of acute lung-diseases. 
Possibly, also, the fact that, as sanitary works proceeded, and the numbers of the people native to the town increased (for many years the numbers were kept up by the immigraiion of strangers), would canse a larger number living who had tided over the perils of the maladies of childhood, yet, being left delicate, would be the more accessible to catarrhal influences.

It will be well to stato here the costs of the structural works made, and of the professional and other labour employed, during the period of 30 years, which have contributed so greatly to the health of the people. The works for water-supply have cost $£ 155,000$. The works for sewers, sewage-irrigation, and filtration, including the purchase of lands, $£ 105,000$ - a total of $£ 260,000$. To this sum should be added the charges for scavenging, gas-lighting, paving, channelling, interest on money borrowed, and establishment-charges for the whole period, about $£ 240,000$; in all, $£ 500,000$. The annual district-rate for the last 10 years has been $3 \mathrm{~s}$. $8 \mathrm{~d}$. in the pound. The present annual

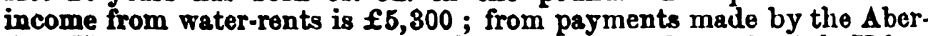
dare Urban Authority, who, together with the Mountain Ash Urban Anthority, use the wide irrigation-areas, and from lands and houses, and profits of farming, $£ 3,620$; thus giving an annual income of $£ 8,920$; while the properties of the local board (that is, the waterworks, freehold lands, houses, otc.) are now estimated to be worth $£ 300,000$.

A consideration of the facts I have stated will bring out prominently two conclusions.

1. Sanitary works well planned, well executed, and thoroughly worked, conduce to better health and longer life.

2. They become a source of profitable income to conmunities.

\section{WATER-SUPPLY.}

From these statistics I pass on to consider certain of the means which were used for the promotion of the health of our people, and will first say a few words as to the water-supply. In doing so, I am sure I shall be telling you all things which each of you has noted; and it is with the object of asking you to reconsider the observations you have made, and regard them in the light which I do, that I ven. ture to ask your attention to the subject.

The water is obtained for the use of the town of Merthyr direct from the lesser Taff River, at a place where it is only slightly exposed to the possibility of pollution from some farm-buildings. It passes at once into a straining basin, and, through some coarsely broken stone and sandy pebbles, into the main supply-pipe. The pipes have a diameter of 14 inches, and through these the water runs for a distance of aix or seven miles. I would ask you to note that the materials used for straining are so coarse as to allow portions of leaves, seeds, cggs of fish, and even the small fry of fish, to pass into the supplypipe. The rock of the district is the old red sandstone, and, after heary rain, the water becomes more or less highly coloured by the fine particles of this sandstone carried down by rain. In the autumn, it is frequently tinged of a brown colour from the presence of peaty matter in suspension. Now this peaty matter adheres to the sides of the iron pipes, and forms a glutinous bed, in which particles of sand are gradually deposited. The result has been that, after only 20 years use, the diameter of the pipes has been lessened from 14 inches to 12 inches.

Now it appears to me that, wherever water for domestic use may be obtained, whether from abundant springs, from a river, or from a reservoir, it should be carefully filtered from all matters in suspension before it passes into the supply-pipe.

The supply-pipes empty into receiving basins placed on a hillside north of the town, and at an elevation of 250 feet above it. In these receiving basins I have observed large trout, minnows, and other fish, and growths of water-plants of considerable length. From these cottling basins the water passes over the rim of a funnel, in a very thin film, downwards to the filtering basins. Watching this thin film Jou would observe much foreign matter, stems of grass, flowers, soods, otc., floating on the surface, being carried onward to the funnol. In the filtoring-basins into which the water is passed, it remains perfectly still, and filters slowly through a deep layer of sand, and you would observe that, while this slow proeess of filtration is going on, water and other plants grow in the water. The water obtained after filtration gives indications of a certain small amount of nitrogen, of chlorine derived from the sand, and of carbon from the vege table matter in solution. Mieroscopic examination displays various forms of minute plants, of bacteria, and of water insect.life. Again, I ske the question, should water intended for human use contain, after filtration, any evidence of the presence of impurity derived from fish, from vegetable decomposition, or from the presence of microbes? The diecoveries in the history of plant-life which have been made known by the inquiries of those greatly distinguished men, Pastear and Davaine, Koch and Hirschfeld, Tommasi-Crudeli and Marchiafava, Steirberg and Tyndall, Lister and Cheyne, and a crowd of others ; the nniversal presence of "the motes in the sunbeam," of the spores of parasitic microphytes in the air, in and around the habita. tions of men, wafted by every wind over hill and dale, their rocognised facility of growth in water-all these point to the absolute neces. sity of devising some mode of freeing driuking-water from all these possible evil influences upon human liealth.

The history of many outbreaks of disease consequent upon the use of milk diluted with inpure water; the known facts relating to the propagation of enteric fever; the recent researches into the mode whereby Asiatic cholera may be propagated; the frequency of attacks of diarrhoea amongst children (water-drinkers) in the autumn, when that fluid most frequently contains decomposing vegetable matter in suspension-all these should direct your attention to the answer which shall be given to the question I have placed before you.

The inquiry being suggested, you will ask -are you prepared with any thonght on the subject? Let me very briefly ask you to recall an experiment which, doubtless, every man here has witnessed when attending his course of chemieal lectures. Under the glass bell of the air-pump was placed a cup of boxwood containing some quicksilver. The air was withdrawn, and the fluid mercury was observed on the floor of the apparatus, having passed through the pores of the wood, leaving, let it be noted, the dross on the surface of the wood. This, to my mind, is what a filter should do; nothing but fluid should pass through it. Of course any matter in solution would not, by filtration, be got rid of, but all matters in suspension should remain on the sur. face of the filter.

Recently, as you are aware, a mode of filtration or separation of all matters in suspension in water has been suggested by the illustrions Pasteur, namely, that of passing water through porous porcelain ; and, while writing this paper, I have been fortunate enough to read in the Journal d Hygienc of May 218t, 1885, an article by M. Mallie, civil engineer, of Paris, in which he describes and figures an appliance illustrative of the principle which Pasteur has mentioned. This ap. pliance, a filter made of unglazed porcelain, is attached to the tap of the house-supply, and thus the pressure of the column of water is utilised to procure rapid filtration. In Ransome's and other filters, a compact and yet permeable material is used; and many varieties of filters may be attached to the supply-pipe of the town or city waterworks, and thus the principle of rapid filtration through a compact porous material is effected ; but, to my mind, filtration through such a material should be done at the source of the water-supply, and that supply should never come into contact with the air until it is drawn from the house-tap.

This is the application of the true principle of water-filtration which $I$ ask you to consider. Hydiaulic power is now so familiar in its application, so all-powerful, yet so easily controlled, that I cannot but believe that sanitary engineers would quickly construct water-filters on Pasteur's principle, of sufficient power and capacity to filter rapidly, through porous stone or porcelain, any amount of water needed, and would do so at a far less cost than is now incurred in making the large and expensive open tanks, which are most unwisely, I had almost said most wickedly, placed in the vicinity of abodes of men, where every facility is given for the contamination of water by floating particles of living matter.

Sewers and Sewre-Vextination.

In the formation of the sewers at Merthyr, care was taken to provide grids or openings for the escape of sewer-gases, which were placed near the summits of the main and lateral sewers. They were to a certain small extent useful, but werc far from being sufficient, as wherever a closet.pan or pipe, or a yard-drain trap, was broken or displaced, there an outburst of sewer-gases occurred. Their deleterions nature was continually demonstrated, for, wherever a case of enteric fever, of diphtheria, or of erysipelas occurred, it was found that a broken trap, or pan, or pipe, in the immediate vicinity, allowed sewer.

gases to escape.
In such a locality as that of Merthyr, where the hilly nature of the land is such that, at a distance of two miles and a half from the centre of the town to the top of Dowlais, there is a rise of 700 feet-in such a locality the ventilation of any underground construction, such as a sewer, should be easily and perfectly effected. Yet this, as I have just said, was not done; and this was due to the fact that the ventilation of the sewers was not carried out on the same principle as that by which underground workings in collieries is conducted. In this great coal-producing district, the principle adopted is to provide a enfficient intake or down-cast shaft for the introduction of a colupn of 
fresh air into the mine, and a sufficient outlet or up-cast shaft for the ontput of all foul air, thus establishing a constant current of fresh air throughout all the workings, which carries with it all the inflammable gases given off from the cosl-workings, forward, upwards, and outwards, into the up-cast shaft, and thence to the open air. It is thus and thus only that the collier is enabled to pursue his dangerous calling. If for an instant the outward progress of the column of fresh air be prevented, either by an airway being accidentally blocked up, or by a doorway to the heading being negligently left open, then the lives of crowds of working men are endangered.

Bolieving this to be the true principle which should be adopted for the ventilation of sewers, I have from time to time pressed upon the members of the Local Board the necessity of providing shafts at the summits of main and lateral sewers for the discharge of foul air, at the same time providing means for the inlet of fresh air at the lowest point of the sewer to be ventilated. Recently, three such shafts have been built, chimneys of 30 feet high, at the summits of as many main sewers, inlets for fresh air being also provided. The result has been (as Mr. Pearson Creswell, the chief surgeon of the Dowlais Works informs $\mathrm{me}$ ) to cleanse the sewers from excess of gases; while the surveyor of the board is so satisfied with the effect produced, that upon his recommendation the board have ordered the building of other stacks, to relieve the sewage-gas pressure in other districts of the town.

Connected with this subject, I nust ask your attention to three matters.

1. The Hopper Closet-Pan.-You all know how generally pans of this kind are used in closets, and you are well aware how liable they are to become choked, and how difficult it is to cleanse them, especially as in a large number of towns there is no provision of a flushing watercistern. At present, no legal power is given to any sanitary authority to direct what kind of pan, or cistern, shall be placed in these conveniences. It is to my mind a want which should be supplied by the enactment of a law giving sanitary anthorities the power to make by. laws to meet this want.

2. Closet Water-Cisterns. - The supply-eistern to a closet is provided generally with a hollow ball-valve; as the cistern fills, the ballfloats and closes the tap. As it is emptied the ball sinks, and the mouth of the tap remains uncovered. Whenever the water-supply, usually constant, is turned off, and after the quantity of water in the cistern is used for flushing, the air in closets will rush into the open service-pipe. Such was the case in Merthyr, in June, 1884. For sotme hours every night the water-supply was turned off, and it was observed that the water drawn off from the house-taps in the morning was " creaming;" it contained a very large quantity of compressed air. Upon examination this air was shown to be impure; the source being foul air from the closet used after the water-supply had been turned of. It is only necessary to mention this imperfection to induce both surveyors of local boards, and manufacturers of these cisterns, to construct some means for preventing the access of foul air into watermains, in the mode described.

3. Sever-Ventilation. - Sanitary engineers still construct sewers with shafts communicating with openings on the surface of the thoroughfares for ventilation. And it is contended that the gases thence escaping into the air, in our lanes and streets, are not injurious to health. How any man who has recognised the fact that diseases have been caused by inhaling sewer-gases can for a moment admit the truth of this assertion, is to me incomprehensible. It is opposed to every fact which Stewart, Budd, Murchison, and Buchanan have proclaimed; it is distinctly opposed by every demonstration announced by Schwann and Pasteur, Tyndall and Lister; nay, it is opposed to our common sense. Can that be harmless which comes from an accumulation of decomposing frecal matter, which is admittedly poisonous when proceeding from a small local deposit? Assuredly not; therefore, as in your minds you are convineed of the danger attending this system; let your pens pourtray the evils of the construction; let your voices be raised against the continuance of so deadly a method; and let sewers henceforth be channels through which fresh air passes, onwards, upwards, and outwards through properly constructed shafts or chimneys, placed at the summits of sewers, far from the habitations of men.

\section{IssPECTION.}

Self-help has been the motto of the people of Merthyr; assiduous devotion to duty the guiding motive of their elected representatives. But there have been gaps in the hedge, which should have been repaired, some lapses have occurred, some delays. These, alas! were the occasions of many fatalities. Yet there were sanitary laws enacted by the legislature which, had they been energetically utilised, might have prevented such lamentable results.
But there was no one to supervise, no one to direct. Zoal in any official is apt to be tired by continual postponements. Year aftar year, during my nearly twenty years' service as a health-oficer, I have. been more and more deeply impressed with the absolute neceserity of regular supervision over the work of all sanitary authoritios. The question constantly recurs " $Q$ uis custodiet custodes ?"

I see the Inland Revenue of the country supervised by well instructed surveyors, having authority over a defined area, and responsible to a central office. I see the work of Poor-law relief carefully watched by gentlemen of great intelligence, who have attained to a thorough knowledge of the laws made for the relief of the poor and of the sick. I see the education in primary and advanced schools overlooked, and the results reported on, by graduates and fellows of our universities. I see the worthy successors of those deroted men who, in times of anticipated trouble, enrolled themselves as volunteers, becoming daily more and more efficient protectors of our sea-girt isle, under the fostering instruction of officers of the first battalion to which they are attached.

Yet, in our branch of the medical prefession, what have we? Dis. jecta membra. No line of work set out; each has to work alone, unsupported by advice, by instruction, without anyone to back him. What wonder is it that those of us who take up Public Medicine, trusting to our reading, our common sense, our honesty of purposeswhat wonder is it that we often "gang awry ;" that, in adjoining dis. tricts, advice diametrically opposite is given to perplezed boards of health?

I can feel that such an accusation as that we have no "consensus" of knowledge would not hold against us if we, as the Volunteers, had near us a medical adjutant officially trained, practically knowing the laws, passing from one authority to another, instructing authorities, advising officials, caring for the sick, as the poor-law inspector does; or taking notes, in his visitations, of the work done, the results pro. duced, the benefits accomplished, as is done by the inspector appointed by the Education Department.

I can imagine that health-officers thus instructed, guided, supported, would, by their concurrent action on a well organised plan, produce results in the way of sanitary improvement as valuable as those which followed the labours of Simon in London City, of George Buchanan in St. Giles's, of Wilson in Warwickshire, of Gairdner in Glasgow, and of Davies in Bristol.

England and Wales, for the purposes of registration, and for the poor-law relief, are divided into 11 districts. There are 15 lay members and two medical members on the Poor-law staff of the Local Government Board. These gentlemen supervise the whole working of the Poor Law. They reside in or near the spheres of their.labonr, are conneeted with the contral directing authority, are in constant communication with the boards of guardians; and thus the great and beneficent duties of administering to the wants of the aged poor, the attendance upon the sick, and the care of each union in a district, are continuously maintained.

Let us turn now to the Medical Department of the same Board: The number of members, including the chief and the assistant modical officers, is 13. Recently, four or tive gentlemen have boen appointed temporarily for a particular inquiry. The special duty assigned, to each of the other members is that of investigating the vaccinationreturns. Each member, let it be especially noted, has a separato district, which is more or less coterminous with the Poor-law and Registration District.

Apart from this special duty, the labours of a member are ambalatory, now inquiring into an outbreak of diarrhoea in Wales, then hurrying to a fever-district in Lancashire; again off into Dorsetshire to finish his vaccination-inspection; then hastily summoned to London; always trotting from east to west, from north to south, the most unquiet of officials.

No one can question the exceeding great value of the inquiries made by the very able gentlemen forming this staff; yet surely it will not be denied that, if definite authority, with recognised respongibilities, were assigned to each one of these gentlemen in some one division, or part of a registration-division, great publio good would result. He would acquire a familiar knowledge of the causes of disease in various locailties; he would be enabled authoritatively to advise as to the best means of removing those causes; ho would direct, guicie, and support health-officers in their difficult duties These, and a crowd of other useful influences, would follow if a member of the Medical Staff of the Local Government Board wero entrusted with the oversight, the regular inspection, of every matter connected with the life, health, disease, and death of the population of the digtrict assigned to his special care.

I am well aware that this matter has been brought before the public 
time after time, but there is a particular reason for now moving in this direction.

The first Report of the Royal Commission for inquiring into the Houxing of the Working Classes has been published. The Commis. sioners say that public opinion must be the moving power. Through this assembly, I appeal to that public opinion to move those who have the power to take this one step forward in the path of progress and of orderly supervision. The step, if taken, would not bo costly, as it would need merely a readjustment of duties, and certain changes of residence from town to country.

I feel convinced that, if sanitary superintendents, having authority in well defined districts, were appointed, in a very few years such a clear elucidation of the removable causes of diseases would be obtained; such definite means for their removal would be pointed out; such a thorongh organisation of an efficient sanitary service would be produced, that the working of the laws for the promotion of the public health would be thoroughly effective, and the benefit to the people inmense.

In making this appeal to you, that this fancy of mine, long held and frequently proclaimed, may be realised, I will "rely upon that, withont which all fancy sooner or later dies, upon that which, once received into the heart, is the basis of untiring faith-I will rely upon Hope."

\section{AN ADDRESS}

DELIVERED AT THE OPENING OF

\section{THE SECTION OF MEDICINE,}

\section{At the Annual Meeting of the British Medical Associa tion, held in Cardiff, July, 1885.}

BY SAMUEL WILKS, M.D., LL.D., F.R.S., Senior Physician to Gay's Hospital ; President of the Section.

\section{ON SOME CAUSES OF DISEASE, AND ON REPARATIVE AND DESTRUCTIVE PROCESSES.}

Ar the annual meetings of our Association, it has been the custom to select one of its most distinguished members to deliver an address on Medicine, and afterwards proceed to the more practical business of the Section. On the present occasion, however, it has been determined to dispense with the usual address, an intention I had fondly inter preted into an eagerness to devote all our time to work. I was in formed, however, a short time ago, that some kind of introduction was expected from this chair. This I heard with dismay, for I had no time to prepare a subject sufficiently elaborated to be worthy of this meeting. You will, therefore, pardon me for making a short address, and alluding to one or two subjects of interest to myself, and which, had time allowed, I should have felt justified in more fully unfolding.

There is a story told of Agassiz, that, at the commencement of his professorship, he prepared a lecture which, he believed, would occupy an hour in delivery, but at the expiration of half that time he found, to his dismay, that he had finished his discourse. He had, therefore, no other resource than to fill up the remaining half-hour by repeating the same doctrines in other words which he had already enunciated. In after years, he used to say that the piece he had been enacting that half-hour, he had continued to do during the rest of his life; that is, he had been stating over and over again the same doctrines which had occupied the first eventful 30 minutes of his coientific career. I do not think that this is a solitary experience, for probably all of us are possessed of some leading thought which, in various forms, as occasion suggests, wo are always endeavouring to impress upon our public. In our profession, certainly, we are witnesses of mon abore the middle age, constantly repeating themselves; and I could turn to many instances in which some of the most respected seniors in medicine have made speeches, the exact counterpart of what they had delivered 30 or 40 years before. This is an attribute of human nature; and I only mention it to show how extremely difficult it is for anyone, who is getting on in years, to free himself from the trammels which age necessarily brings with it, and what a hard task you set an oldish man by expecting anything of him which can be called new. If science is advancing, we ought to grow with the times; but, unhappily, there is a period in everyone's life when his stature is reached, and he then stands still ; fortunate is ho if he can remain quiescent, and not fall back, reaching at last that stage of senility when he is only a "laudator temporis acti," and thinks that human nature, with its types of disease, has altered, and medical treatment retrograded, with his own decay.

For my own part, if special reasons had not stood in the way, I should probably have been repeating myself here, and setting free once more the long continued current of my thoughts. And what might these have been in connection with the science and art of modicine? The best method, I believe, to arrive at anyone's sentiments or opinions is to study his actions ; and if I do this with myself, and look back to the aililresses which I have given at this Association, at my hospital, or at the International Congress, I find the theme is the same. It is one which had its basis formed at a very early period of my career, and became more fixed as years and experi. ence went on. It was this, that the peculiarity of different races of mankind must depend on climate, food, and other surroundings, and that these peculiarities are transmitted; that hereditary tendencies have, therefore, much to do with the physical and mental characters of individuals, and also that these temperaments and idiosyncracies which are so evolved are most important in the production of our ailments; again, that these surroundings are, in themselves, sufficient to produce active disease-for example, a number of conditions tend to the prevalence of the gouty constitution in England, and this may be carried through several generations, but the same conditions, operating on an individual predisposed, may actually induce an attack in him: that the predisposing and exciting causes are the same. Morbus Brightii, and many other diseases, come about through the deleterious operation of our ordinary surroundings, both in the air wo breathe and in the food we eat, and not from any well defined specific cause. I have, therefore, considered that nearly all disease is slow in its origin and progress, and I have never been tired of quoting Hippocrates, the father of medicine, who said, "Diseases do not fall upon men instantaneously, but, being collected by slow degrees, they ex. plode with accumulated force." I thought I saw, even in my student days, how erroneous the books and lectures were in giving descriptions of acute disease as occurring in healthy persons, and then how such affections became at last chronic. The truth, as I saw it, was very early forced upon me by making post mortem examinations; when, for example, a person was brought to the hospital for obstruction of the bowels, attributed to an intussusception, of the lodgment of some indigestible food, and which proved nearly always to be due to a cause of very long standing, or even congenital ; in the same way, acute peritonitis was but the termination of some old disease in the abdo. men, and a meningitis the ending of a prior disease in the brain. I had thus come to look upon disease as essentially chronic in its nature, induced by the ordinary agents surrounding us, and to believe that the medical art should be mainly directed against the operation of these causes. I have no doubt, had I given an address, and shut my eyes to all the discoveries going on around me, I should have wandered back to the old theme, and found all my opinions confirmed by ago. I cannot, however, be blind to what is now occupying the medieal mind, and therefore with all sadness confess the truth, my occupation's gone. It is of no use talking any longer of the conditions of our climate pre. disposing to phthisis ; of the hereditary tendency to this disease, much less of any peculiar conformation of chest and frame in those who fell a prey to it, for the disease is due to a bacillus, which may be taken by a husband from his wife, or vice versa, or conveyed by a phthisical nurse to a number of children whom she suckles, or even, indeed, caught in the street; at least, this was suggested in the case of a lad who died of tubercular meningitis, having long had a sore tongue, which was called tubercular. It was surmised that it was primarily a simple ulcer, on which bacilli alighted as he ralked through the streets. In order to mollify believers in predisposition, temperaments, and configuration, it is admitted that there must be appropriate soil for the cultivation of the germs; but, after the delivery of these platitudes, they are put on one side for the study of the one potent agent, the bacillus, and are no more considered than predispositions to small-pox, scarlatina, or cholera. I do not for a moment attempt to throw any discredit on modern research, for these bacilli undoubtedly exist, as any one may prove for himself; but I am rather offering myself for pity, that, having preached on one long text, that it is the great aim of the physician to seek the causes of disease in our ordinary surroundings, and in the tendencies transmitted to us, and to try to remove them, I find my occupation gone; but perhaps I am only shunted for a time to let the express pass by.

It might be worthy to remark, in passing, how treatment accompanies and follows pathological discoveries, in opposition to the mis taken idea, which many seem to hold, that there is a science of therapeutics gained by a simple observation of the action of drugs on the body. It is sometimes said that therapeutics stands still or lags behind other departments of medicine. I think this is not true, and 